\title{
Applicability of Large-Span Structures for Presentations of Archaeological Sites
}

\author{
Natasa Zivaljevic-Luxor ${ }^{1}$, Hartmut Pasternak ${ }^{2 *}$ \\ 1 Dr Nataša Živaljević-Luxor, Director of National Heritage Foundation, Serbia; luxornatasa@gmail.com \\ 2 Professor Dr.-Ing. habil. Hartmut Pasternak, Full Professor, Brandenburg University of Technology, Cottbus, \\ Germany, h.pasternak@arcor.de \\ * Correspondence: h.pasternak@arcor.de
}

\begin{abstract}
The purpose of the study was to provide support in the decision-making process for architects and engineers regarding large-spans structures for the presentation of archaeological sites in situ - construction of roofs, shelters, and bridges. We examined existing practice and analyzed their engineering classifications looking for a pattern in their application regarding sustainability and relation between type of cultural heritage site and type of applied large span structure. Contemporary engineering structures at built heritage sites create a sharp contrast between old and new. A presentation of cultural heritage in situ requires an understanding of heritage theory and internationally accepted doctrine which exceeds common engineering education. Nevertheless, application of large-span structures, which often take advantages of state-of-art construction-technologies nowadays, is also an aesthetical statement that affects the appearance of the site. Therefore, we gave an overview of the theoretical background of aesthetical issues and the overall ethics of the decision-making process in such sensitive cases. Within the framework of heritage-presentation, engineering and architectural issues, and selected case studies, we concluded in favor of the application of large-span structures under certain conditions.
\end{abstract}

Keywords: archaeological site, roof, shelter, bridge, sustainability, aesthetics, heritage presentation, decision making

\section{Introduction}

Archaeological excavations have been made for several centuries, yet new archaeological sites constantly emerge and sometimes they require presentation in situ. Such presentations, in addition to other built-heritage sites often require the construction of large-span structures as roofs, shelters and bridges. Archaeological sites are most numerous among heritage sites which require an application of large span structures. The purpose of the study was to provide support in the decision-making process for architects and engineers regarding large-spans structures for the presentation of archaeological sites in situ. We examined existing practice and analyzed their engineering classifications looking for a pattern in their application regarding sustainability and relation between type of cultural heritage site and type of applied large span structure. Our focus was primarily on steel structures, but not exclusively.

\section{Materials and methods}

We chose case studies among archaeological sites which origin from historically Eurocentric areas. "The Old World" offers rich scope of archaeological sites in variety of shapes, size, constraints etc. implying that the result is probably valid for any area. 
Besides case studies, scientific method includes comparison, synthesis, generalization and modeling of the decision-making process. The decision-making process of architectural/structural design has standard steps and additional steps which appear due to the nature of built-heritage sites, large-span structures and heritage presentation rules.-

\section{A look into the past}

There is a long tradition of setting shelters and roofs above the archaeological finds, both when they are presented in situ and when they are not. Since the beginning of 20th century built heritage was exhibited in museums especially built for that purpose (Fig. 1 shows the roof construction above the Pergamon Altar in Berlin [1]), while in other cases roofs and shelters were built above archeological finds in situ, in both cases as protection from precipitation, releasing weathering, aging and similar. In both groups of cases the purpose is essentially the same - to protect, though demands may vary.

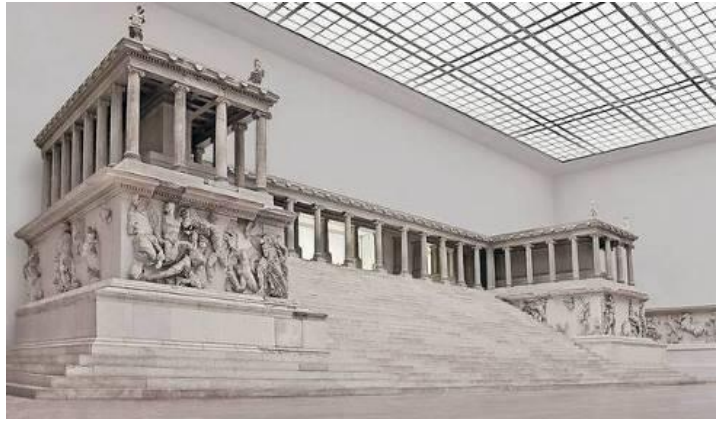

(a)

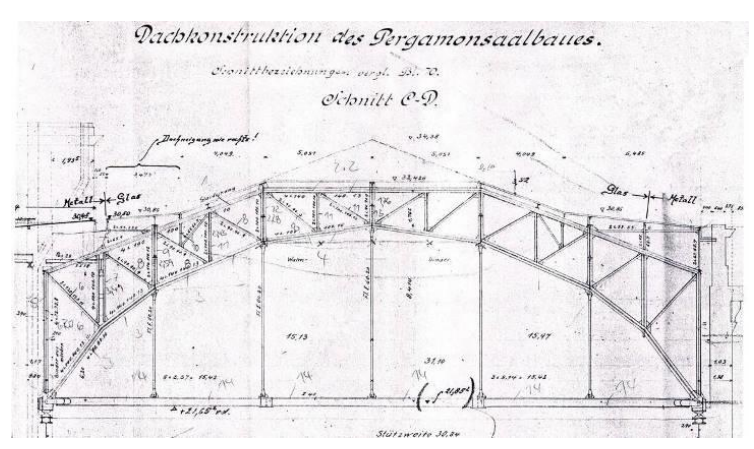

(b)

Figure 1. The roof above the Pergamon Altar (Berlin, Germany) erected between 1910 and 1930. It has ca. 30 m wide span steel truss covered by glass with a false ceiling, which lets in natural light; a) interior; b) truss section.

Many case studies of protective buildings for archaeological sites presented in situ have been published by now, therefore, the following chapter gives only an overview of possible structural designs of roofs and shelters.

\section{Subjects of roofing, sheltering and bridging}

Roofing and sheltering comes from a need for protection of archaeological finds, and architectural and other structures in situ from a variety of influences (e.g. precipitation, UV, pollution etc.). A need for bridges emerges in an attempt to avoid collision of opposing spatial requests (in other words - as a way to cross over an archaeological site, typically, by linear infrastructure instead of going around), or as a tool in a presentation or another stage of heritage protection. In the second case, pedestrian bridges are typically used to provide a better view of a heritage site, avoiding, at the same time, the danger of destroying surfaces of historical structures by walking on them or in their immediate surroundings. These are the cases that we identified, however other circumstances are possible. For the needs of this research, we make a distinction between those reasons which originate in actions for protection and which are particularly important for architects and those who emerge as an outcome of the conflict in land-use between built heritage and entirely different purpose, which are more important for urban planners and infrastructural engineers. This categorization is useful for further discussion of the ethics of interventions.

Relation between architectural period and span is difficult to find and there are two reasons for that. Firstly, throughout history, there are proofs of urge for records in construction (in length, height, volume etc.) and in practice, there are no "standard" spans for a particular period. Historical "periods" in Eurocentric architecture naturally come out of the prevailing use of materials, construction technics and their aesthetics. The constraints of construction technics can be used as an indicator of expectable spans in 
some cases. However, natural materials have been used through centuries for large spans with great success. Only later, in the Industrial age, new materials and new possibilities emerged, and yet many "old" records were still standing for a while longer (illustrated in Fig. 2; [2]).

It is fair to mention that popularity of high-rise buildings of the industrial age was encouraged less by the structural potential of materials and more by other inventions which led to massive production of electricity and common use of elevators. The old construction technics were surprisingly efficient in resolving large spans using stone, brick, wood, small amounts of scarce and expensive iron, traditional concretes and mortars. For facilitating an overview, we remind a reader of a few sets of otherwise commonly known data (see Table 1).

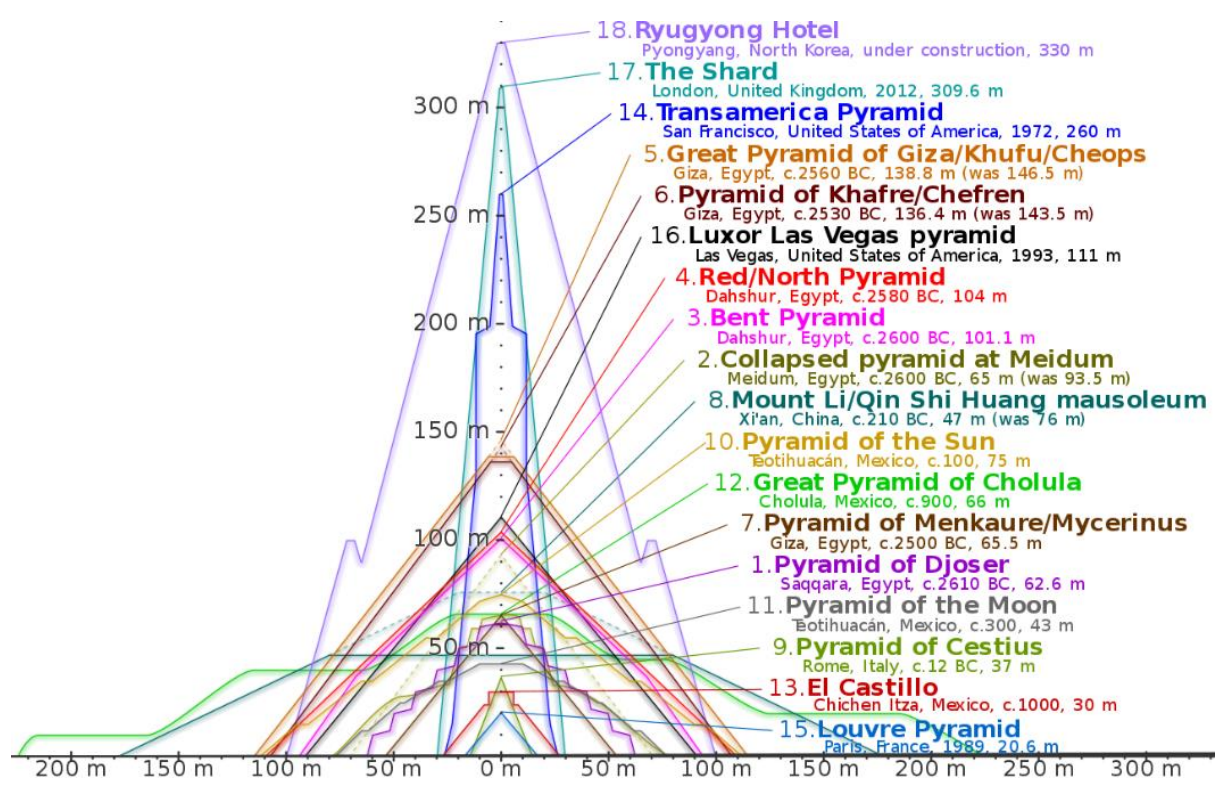

Figure 2. Brief overview of spans through history based on the comparison of iconic buildings.

Table 1. Examples of common and maximum spans for iconic buildings from Renaissance to early Industrial age.

\begin{tabular}{|c|c|c|c|c|}
\hline Type of structure & Common span & Biggest known span & Note & Date \\
\hline Trusses & $20-26 m$ & $30.5 \mathrm{~m}$ & $\begin{array}{l}\text { Triangulated truss- } \\
\text { a Palladio }(5 \times 13 \mathrm{~m})\end{array}$ & $16^{\text {th }} \mathrm{c}$ \\
\hline Nave of Gothic church & $13-16 \mathrm{~m}$ & $23 \mathrm{~m}$ & $\begin{array}{l}\text { Gerona Cathedral } \\
\text { - the widest nave }\end{array}$ & $1015-1038$ \\
\hline Dome & & $\begin{array}{c}42 \mathrm{~m} \\
34.2 \mathrm{~m}\end{array}$ & $\begin{array}{c}\text { in Florence } \\
\text { by Brunelleschi } \\
\text { in Rome } \\
\text { St. Peter's Basilica } \\
\text { In London } \\
\text { St. Paul's Cathedral }\end{array}$ & $\begin{array}{c}15^{\text {th }} \mathrm{c} \\
1506-1626 \\
1675-1710\end{array}$ \\
\hline $\begin{array}{l}\text { Girders - wooden roof } \\
\text { Cast iron } \\
\text { Wrought-iron roof trusses }\end{array}$ & $6-13 m$ & $\begin{array}{c}20 \mathrm{~m} \\
30.6 \mathrm{~m} \\
28 \mathrm{~m}\end{array}$ & $\begin{array}{l}\text { Uffizi by Vasari } \\
\text { Bridge over Severn } \\
\text { Theatre Française }\end{array}$ & $\begin{array}{c}1560-1581 \\
1779 \\
1786\end{array}$ \\
\hline
\end{tabular}

Later use of artificial materials with greater potentials did not fundamentally affect spans for construction of buildings, as we might expect, simply because human ergonomic needs remained the same. Quite the opposite: the other factors as demographic 
growth and need for time/resource/energy efficiency encouraged optimization of spans in habilitations and they became even smaller than before.

Secondly, a subject of protection may be a single building or part of it, as well as e.g. agglomeration of buildings. In some cases - if the agglomeration is considered the most valuable, required spans may be tens of times bigger than spans used in the construction of a single unit (Fig. 3).

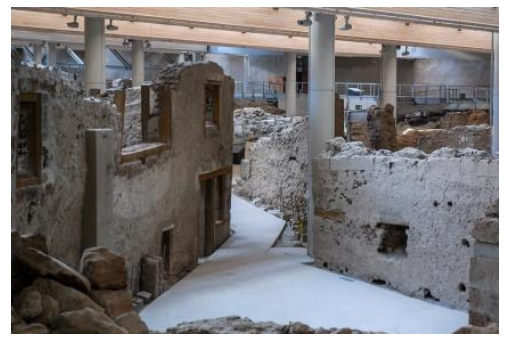

(a)

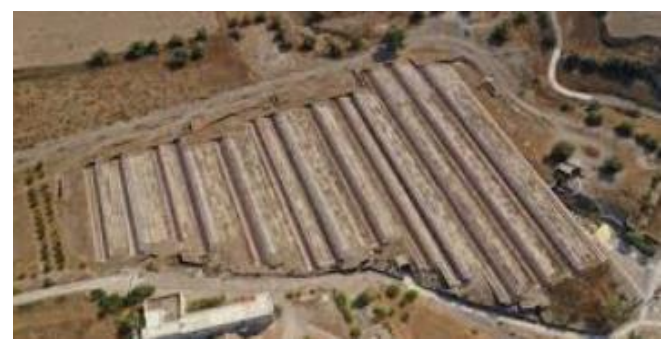

(b)

Figure 3. This Santorini, Greece, Archaeological site - prehistoric town of Akrotiri preserved due to volcano eruption: (a) single units and agglomeration; (b) aerial view of the roof. [3]

\section{Structural design possibilities}

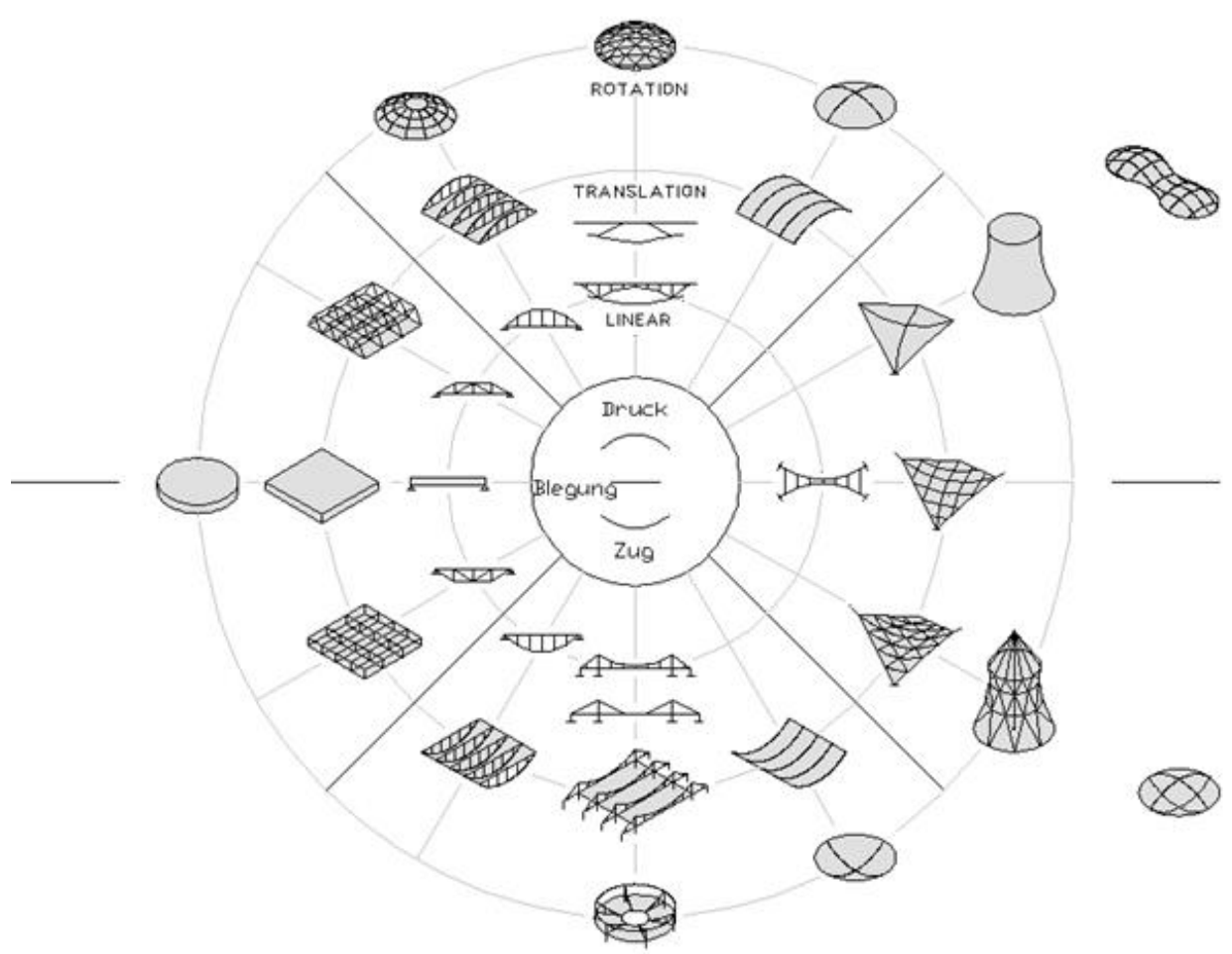

Figure 4. Types of structures. [4]

In general, there is a great variety of possible constructions, and some are shown in Fig. 4 [4]. Later, many new types of structures were invented. The main structural members are subjected to either compression or bending or tension. The possible scope of solutions narrows when required spans are taken into account. Spans can be frequently used as eliminating criteria in an early phase of decision-making. Such structures are typically not built on site, so possibility of transportation to the location and mounting may also be eliminating criteria. 


\subsection{Girders}

The Pallas of the castle (from around 1250) in Vlotho has been reconstructed before the WW II. A contemporary designed shelter from steel was added, along with works on reconstruction of the castle after 2000, giving an idea of how the original building looked like (Fig. 5). The optimum span for hot-rolled girders is up to $9 \mathrm{~m}$.

All figures and tables should be cited in the main text as Figure 1, Table 1, etc.

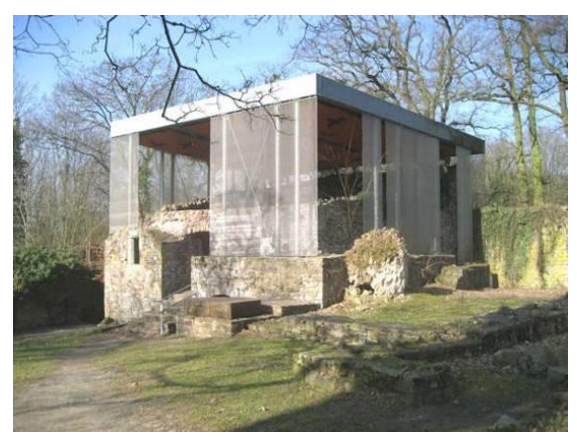

Figure 5. Medieval Pallas in Vlotho, North Rhine Westphalia, Germany. [5]

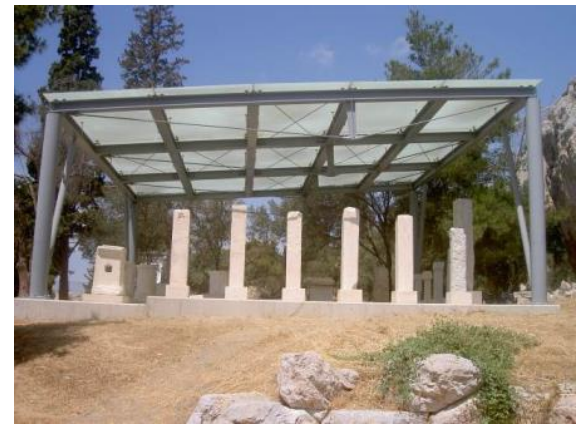

(a)

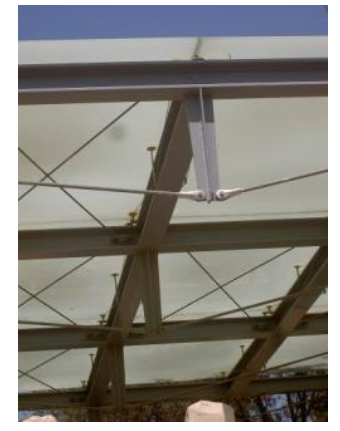

(b)

Figure 6. Acropolis, Athens, Greece: a) overview; b) detail. [6]

\subsection{Strut trussed girders}

Strut trussed girders consist of hot-rolled profiles and round steel. They have the optimal field of application between $9 \mathrm{~m}$ and $20 \mathrm{~m}$. The advantage of those girders lies in smaller internal forces and deflections under uniform loading than for simple girders. This results in slimmer steel construction of the roof, which combines well with glass (Fig. 6). A solution with a slim beam was used behind the House of Martin Luther (1483-1546), the Initiator of the Reformation. One strut runs over the beam, the other under it (Fig.7). The roof (built in 2010) over the ruins has span of $22 \mathrm{~m}$ and applies a combination of steel and PTFE foils. 


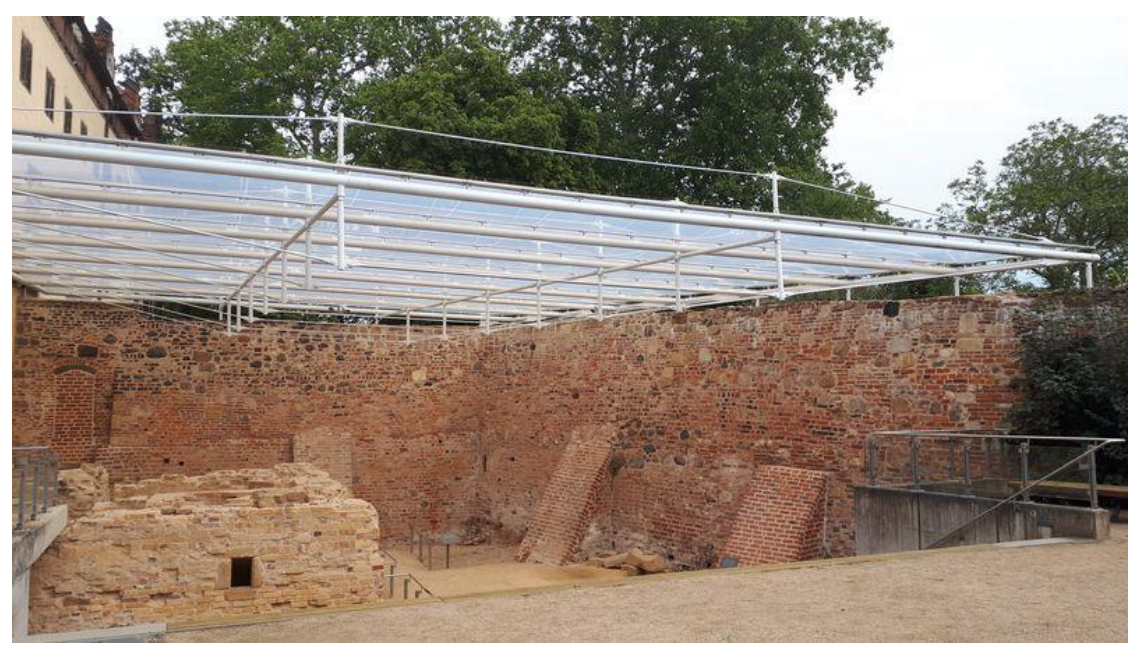

Figure 7. The roof over the ruins behind the house of Luther, Wittenberg, Germany. [7]

\subsection{Frames}

Finds from the Byzantine time, situated near the Ohrid Lake, were sheltered with traditional members (Fig.8). This frame consists of hot-rolled hollow sections and has a span range of up to $15 \mathrm{~m}$.

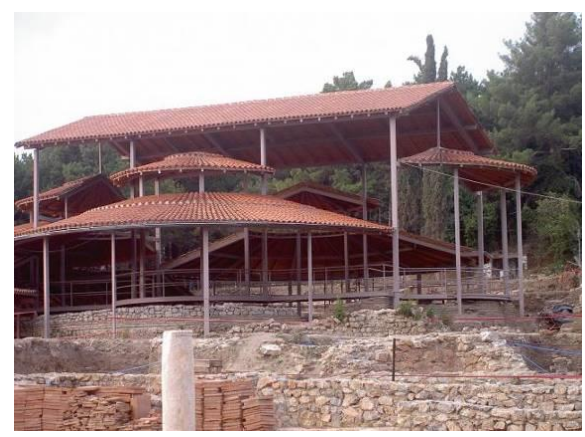

Figure 8. Shelter in Plaosnik near the Lake Ohrid, North Macedonia. [8]

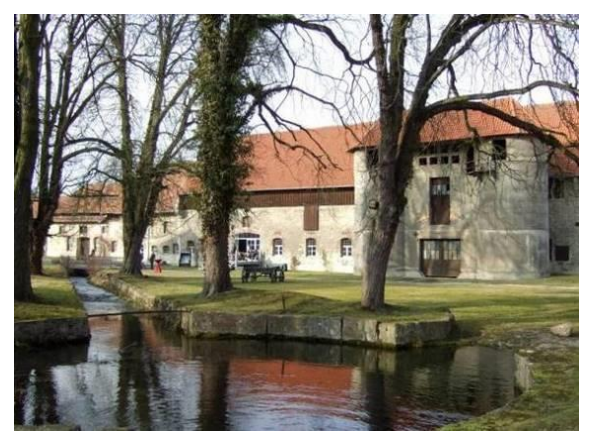

(a)

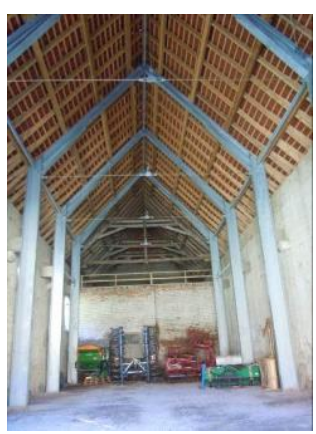

(b)

Figure 9. Heritage agriculture building with preserved walls and steel frames in Lucklum, Lower Saxony, Germany: a) exterior; (b) interior. [9]

In the following example, the masonry walls have been too weak for the construction of a new roof on it, in an agriculture building in a manor from the 17th c (Fig.9). Therefore, the steel frame is set inside to preserve the outer historical view. In the case of welded sections, spans of as many as $80 \mathrm{~m}$ are possible. 


\subsection{Trusses}

Trusses (with a single upper and lower chord) have a span optimum between $15 \mathrm{~m}$ and $30 \mathrm{~m}$. They are convenient for combining with glass or translucent membrane. Figure 10 shows the roof near the center of Athens which covers a Roman Bath.

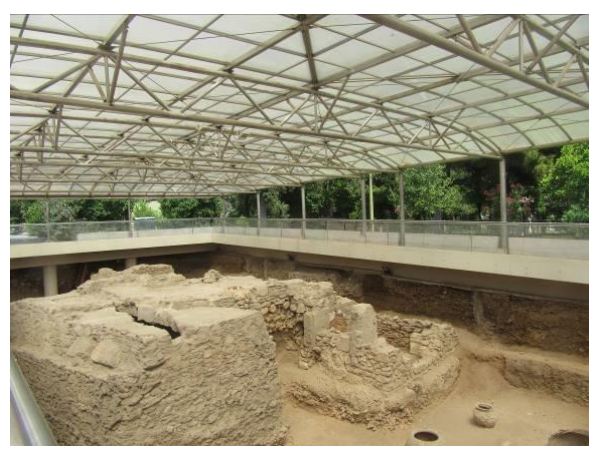

Figure 10. Truss roof, near the Syntagma square in Athens, Greece [10]

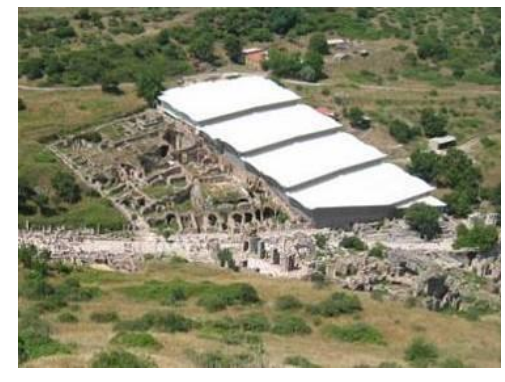

(a)

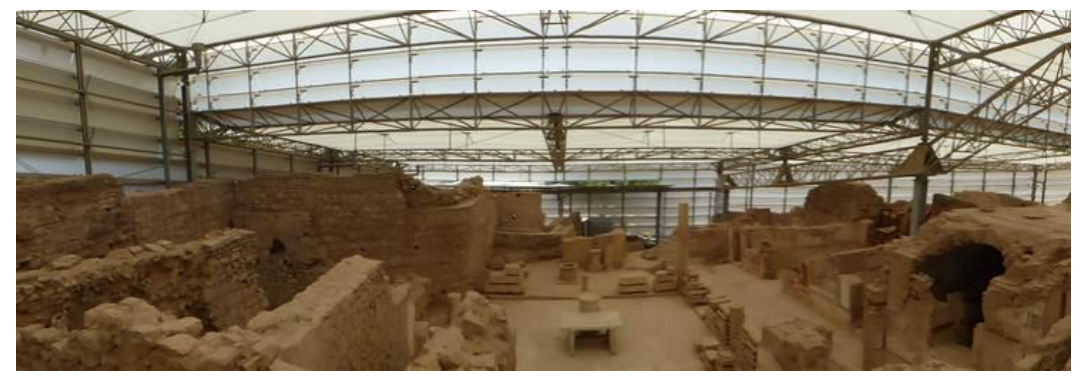

(b)

Figure 11. Ephesus, Turkey: a) exterior; (b) interior. [11]

The Hamar Cathedral (Fig. 12), which is located 100km north of Oslo in Norway, was built before 1152 and destroyed by the Swedish army in 1567. What was left of it (mostly remains of arches) is now protected by a truss construction.

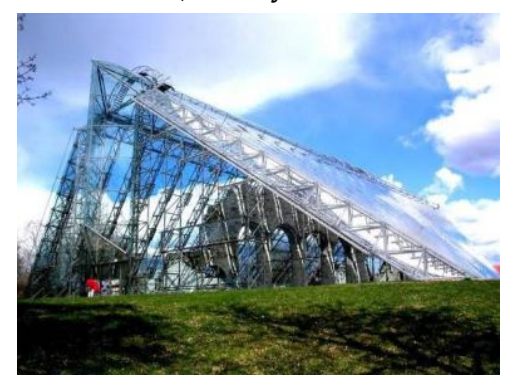

(a)

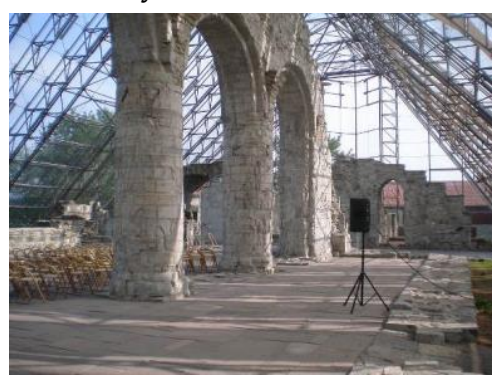

(b)

Figure 12. Hamar, Norway: a) exterior; (b) interior. [12]

\subsection{Arches}

Generally, arches allow widest spans. Fig. 13 shows a two-hinged steel truss arch above the middle-stone-age and Neolithic site in Lepenski vir, which is situated outside of urban area, by the River Danube. Prehistoric temples in Malta, a WH site, are well preserved and later sheltered by a structure with arches. 


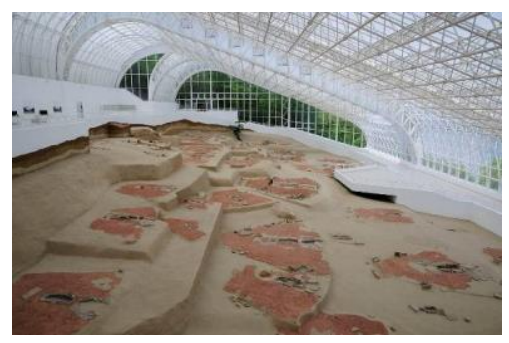

Figure 13. Prehistoric archaeological site Lepenski Vir, Serbia. [13]

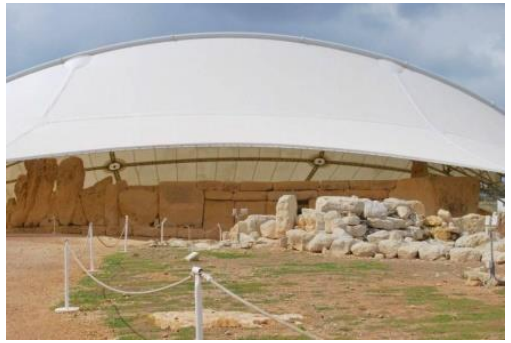

(a)

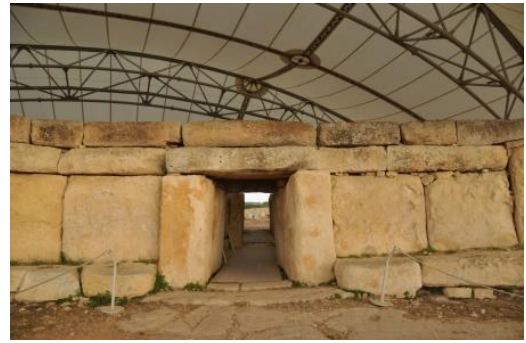

(b)

Figure 14. Hagar Qim, Prehistoric temples in Malta: a) exterior; (b) interior. [14]

\subsection{Shells}

Pig iron first flowed from the blast furnace of the St. Antony ironworks in 1758. Today, this first ironworks in the Ruhr region is part of an industrial archaeological park. The $900 \mathrm{~m}^{2}$ shell roof has 323 similar panels overlapping each other like shingles. Due to their double-curved shape and rigidity, the shell is self-supporting and does not need any welding (Fig.15).

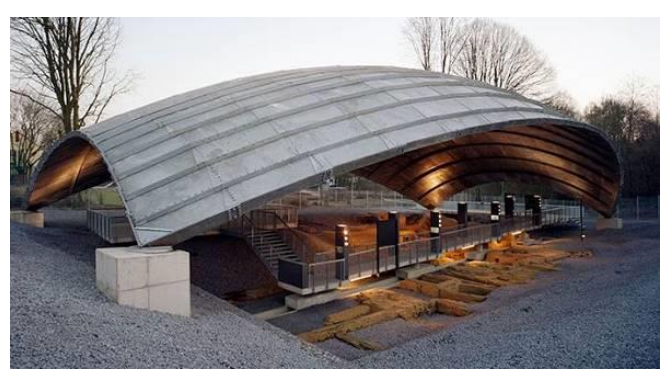

Figure 15. Oberhausen, Germany. [15]

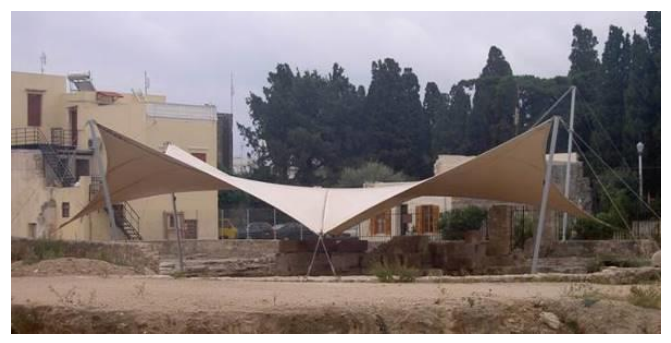

Figure 16. Tent above archaeological site in Rhodes, Greece. [16]

\subsection{Tent structures}

When the climatic conditions allow it, a simple awning may be satisfactory (Fig. 16). A more demanding example is the Kufstein Fortress (Fig. 17). For high-quality events, weathering protection is important. It happened few times that concerts literally fell into the water in bad weather, while other events never happened because of financial risks. 
Thus, the idea arose to make the largest possible part of the fortress weatherproof by a temporary retractable protective roof.

Strict requirements of the monument protection had to be considered, which did not allow anchoring in the historical structure. The appearance of the fortress had not to be affected by the new construction. In order to meet these conditions, so the planners developed a filigree, centric cable structure, from which a membrane can be stretched. This convertible canopy allows covering $2000 \mathrm{~m}^{2}$ over the entire fortress yard and part of the casemates in 4 minutes. In good weather, the membrane is situated in the center.

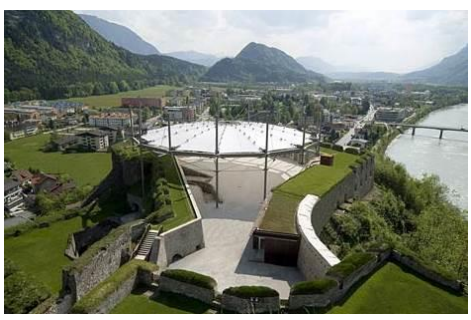

(a)

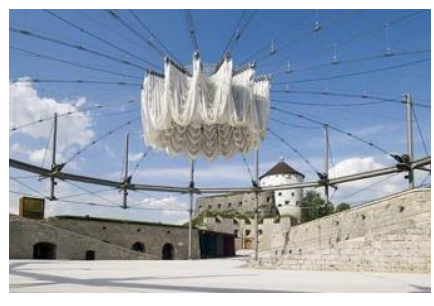

(b)

Figure 17. Fortress Kufstein, Austria: a) exterior; (b) interior. [17]

\subsection{Double-curved cable net structures}

Double-curved cable net structures with a circumferential edge girders usually have their support at both low points. They allow a large area to be spanned without supports. German examples are the Customer Centre in the Autostadt Wolfsburg (2013) and Schierke Arena in the Harz Mountains (2016/17) [18]. They allow having no columns in the viewing area and also spanning the whole arena. With the additional use of membranes as the roof shell, the inside of the building will get naturally lighted.

Another version of the double-curved cable net structures has been used by the German investor Deutsches Archäologisches Institut to cover the ruins of Göbekli Tepe in East Turkey at the border to Syria. With its monumental, ring-shaped structures from the period between 10,000 and 8,000 $\mathrm{BC}$. the excavation site is currently one of the oldest known ritual buildings of mankind. The light membrane roof, spanned over a cable network, is held by a circumferential, elliptical compression ring on inclined steel supports. The structure has a span of approx. $39 \mathrm{~m} \times 45 \mathrm{~m}$ and an arch rise of $3.6 \mathrm{~m}$ and covers $1,350 \mathrm{~m}^{2}$.

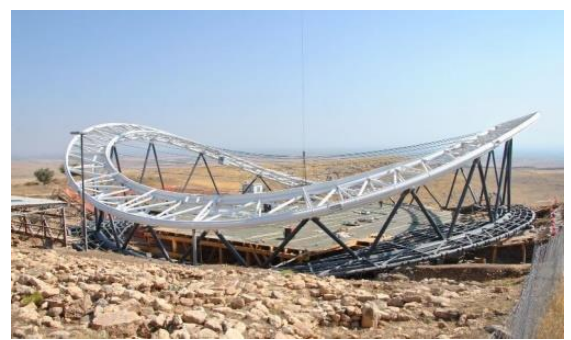

(a)

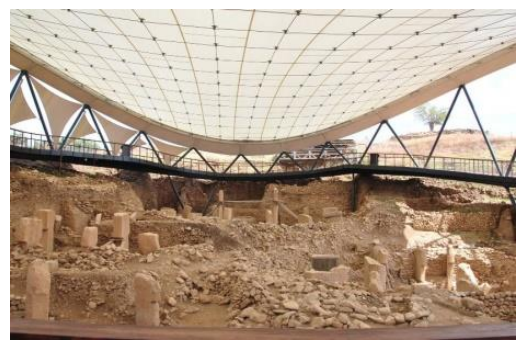

(b)

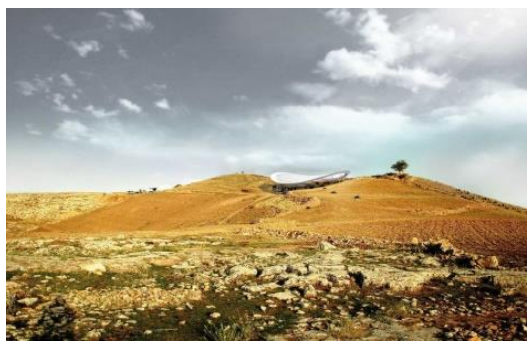

(c)

Fig. 18 Cablenet over the ruins of Göbekli Tepe. [19]

Due to the large spans and eccentricities, the construction of the walkway in connection with the roof ring is basically designed as a support ring consisting of two curved trusses (Fig. 18a). The two lattice girders have their upper chord in the roof level and their lower chord in the pedestrian walkway level (Fig. 18b) A major challenge for the structural planning was the support of the construction on the few, irregularly distributed foundation points of the excavation site. 
The result is a light structure with a good portability that fit into the hilly topography. (Fig.18c). The shelter was finished in 2016.

\subsection{Bridges}

Bridges are clearly distinctive from those previously mentioned structures and they serve different purposes, as explained in chapter 3. The example in Fig.19 shows pedestrian bridges which serves to allow safe access for visitors of the archaeological site of Roosenberg Abbey from 13th century (Belgium).

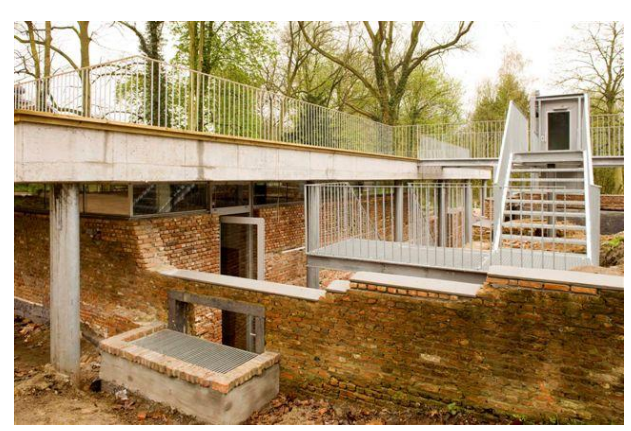

Figure 19. Ruins of Roosenberg in Belgium. [20]

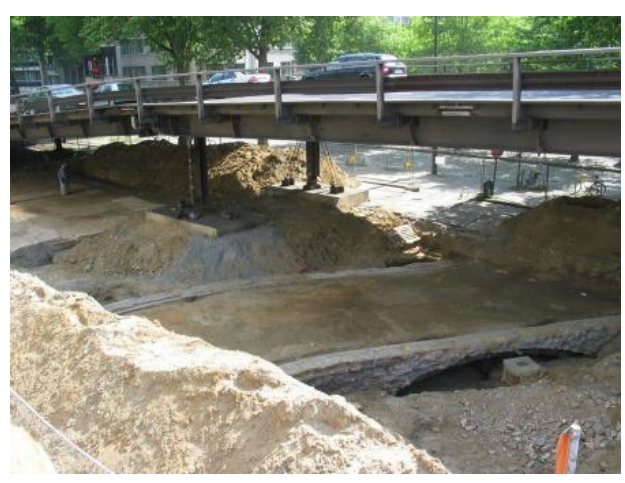

Figure 20. Brug Kipdrop in Antwerp, Belgium. [21]

The other example of the bridge over archeological site (Fig. 20) shows that walkable coverings gained importance. Under the bridge, there are parts of Spanish ramparts around Antwerp from 16th c. The future of this archaeological site is uncertain [22].

\section{Heritage and ethics of intervention}

Intervention is never neutral, and therefore we should be aware of the ethical meaning that interventions carry concerning heritage sites. Underneath a simple statement "ICOMOS allows new structures at archaeological sites if they are clearly distinctive", there is a lot of work of heritage theoreticians and practitioners, and a set of unspoken rules of thumb.

For many engineers, heritage rules (and in particularly aesthetics of intervention) are perceived as "terra incognita" or "a minefield". This comes essentially for two characteristics of heritage protection as a discipline. It relies both on theory and doctrine which is a phenomenon typical for social sciences, and that could be confusing for practitioners in technical sciences. Moreover, the theory had early progress roughly at the end of the 19th c and beginning of the 20th c, then its establishment in the middle of the 20th c, followed by the period of fragmentation in the second half of the century (like many other disciplines in social sciences) without a clear streamline and without univocal acceptance. Its development led to the first integrated general theory in the early 1970s 
which, nevertheless, left many issues undefined, in particularly regarding architectural problems (which typically happen to be an exceptional case, unlike any other art or science). On the other hand, heritage doctrine experiences profusion since the second part of the 20th c resulting in enormous number of resolutions, declarations and other documents, generated by numerous international and national stakeholders, which may be sometimes (if not often) difficult to trace and interpret.

Ethics of intervention consists of two elements: if intervention is "moral" and if it is aesthetically acceptable. The first part may imply questions as: does intervention change the nature of subject of presentation, are the author's rights (known or unknown) violated by intervention and alike, which can be proofed through symbolic analysis. This problem can be briefly summed up by the following comparison (paraphrased): it is not possible to build a highway to the top of Mont Blanc without causing that it becomes something completely different [23]. Applied on built cultural heritage, this rule refers to the problem if intervention reveals understanding and respect for the heritage at stake according to the reasons for protection. Fig. 21 illustrates an example of a pedestrian path across the fortress, for a fast connection between center of the city and technical university, across the area of the fortress which very rich in archaeology and that has been resolved by the bridge across rampart. Any fortress is defined by its walls and gates. Although this communication could have been solved through the gate located $50 \mathrm{~m}$ further away, it was resolved by the bridge across the rampart - concept which was in the Middle Ages seen only in times of war and usually punished by death, and which aesthetically and symbolically violates the spatial integrity of the fortress (if the fortress is perceived as an obstacle, it should be demolished, e.g. as Viennese ramparts, and not preserved with hypocrisy) [24] [25].

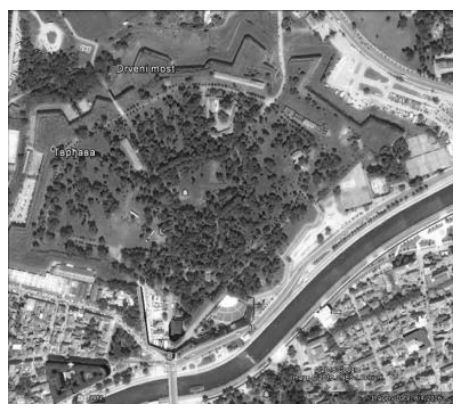

(a)

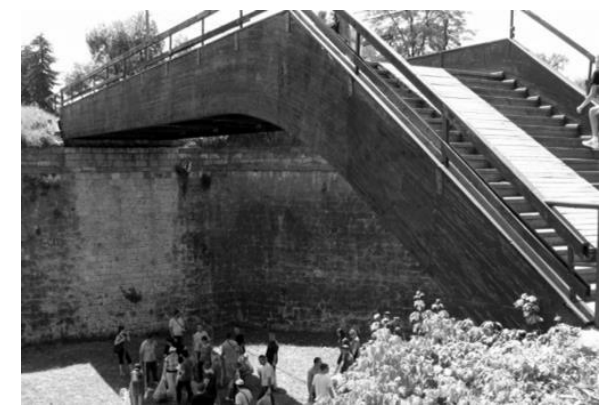

(b)

Figure 21. The Fortress of Nish, Serbia - the wooden bridge over the north-western rampart: a) aerial view; (b) photo.

At a more theoretical level further beyond, every time when we present architectural object as an artefact, we change its nature from a functional structure with practical use into something else - an exhibited item. We do not object to shelters and roofs being applied if that is what is needed to keep endangered heritage for further generations, but we consider it fair to clearly state what such action implicates in an ethical sense. Although all documents of international heritage doctrine "touch" ethics of intervention, some deal with that more than the others:

- Venice Charter (1964)

- Convention Concerning the Protection of World Cultural and Natural Heritage (UNESCO 1972)

- The Burra Charter (1979-2013)

- Nara Document on Authenticity (1994),

(on which agree several authors - dealing with heritage ethics e.g. [26] [27]

And two important documents referring to information technology and $3 \mathrm{D}$-visualisation as a tool of restoration; 
- The Charter of Krakow (2000);

- The London Charter (International charter for the computer based visualization of Cultural Heritage) (2009);

Aesthetics of intervention is another element of the problem, which deeply correlates with the first one to a trained eye. Creating shelters and roofs changes the visual perception of a heritage site. This aspect has been well explained by Gestalt psychology already in the middle of the 20th c. The general theory of restoration emerged in a circle of Italian theoreticians in the middle of the 20th c. It is considered essentially an aesthetic theory and offers an answer to the previous problem. According to this theory, a new structure on a heritage site is acceptable if it is clearly distinctive and if it is a work of art [28]. The first criterion is actually related to the issue of authenticity and plagiarism, and it is not a big challenge in the case of contemporary large-span structures (they are naturally very distinctive in the surrounding of built heritage). The second one was once a demanding criterion, but nowadays, the use of software for visualization reduces the challenge to the repetition of attempts, until a satisfactory result. The software which supports the design of free forms (e.g. Rhino, Grasshopper, ArchiCAD, Fusion 360 etc.) indicate that the design will stand alone in its environment.
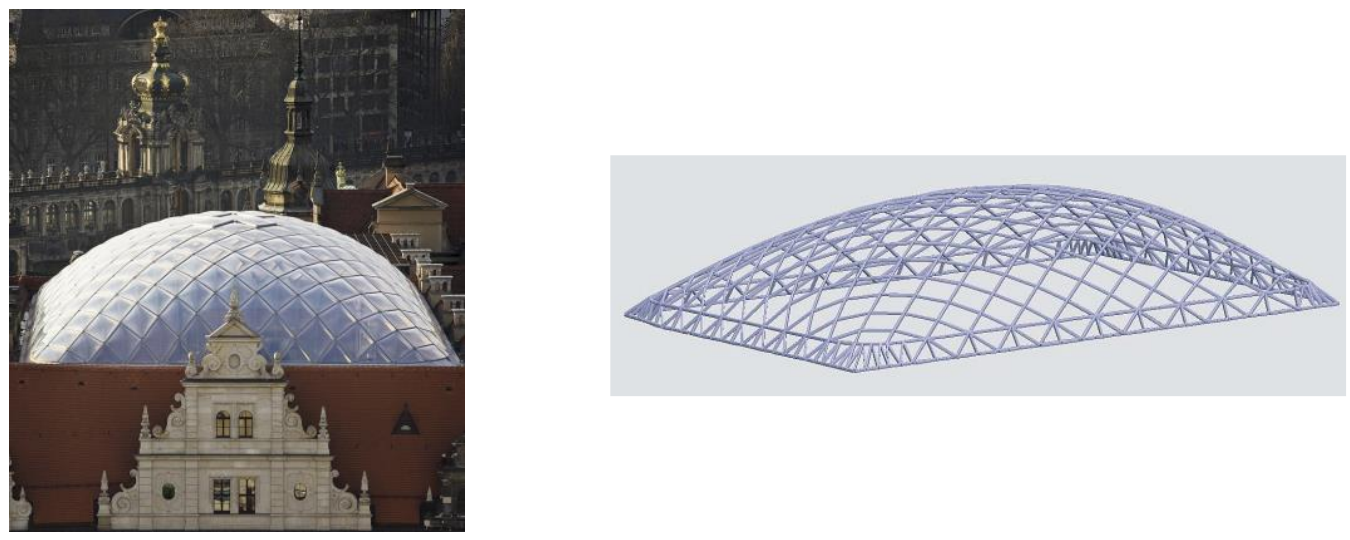

(a)

(b)

Figure 22. The roof above a small yard of Dresden Castle, a Renaissance building in the center of the city, demonstrates the application of shells. The castle was the residence of Saxon electors and kings, it was damaged in a bombing by the allies on February 13, 1945 and later rebuilt. In 2009 a steel grid shell with foil cushions was added; the structural model shows a framework dome, which consists of a grid shell and surrounding edge truss girders at the dome base [29].

Theories of architectural aesthetics can be studied from Homer's epics and origins of Western civilization until the middle of the 20th c and the great war between Aestheticians and the Avant-garde, and beyond, however, this route takes time. For practical purpose, there are rules of thumb which are generally well known: e.g. interventions which can be described as mimicry, copy-paste or imitation of historical structures do not lead to good results while honesty, authenticity, originality and creativity generally do, and it proves practically that either way it is all about ethics. However, according to the same theory [28], it is not possible to create a work of art intentionally; therefore, no rule should be taken literally and out of the context. The following example illustrates one of the iconic interventions on heritage building (Fig. 22). The design of a new structure is fully contemporary and resolves a real problem in the present time. However, cumulative of effect of numerous interventions in Dresden led to it that it lost WH status in 2009 which was based on impact of the Waldschlösschen Bridge on the River Elbe on its landscape with heritage values.

Finally, we want to point out the distinction between the aesthetics of existing heritage building and the aesthetic of a new structure. The existing building may be preserved for various reasons including historic and scientific or documentary, and for such reason its aesthetic may be aesthetic of ugliness (e.g. memorials of war crimes), coming 
from any historic period, while aesthetics of the new structure cannot be such and its design has to belong to the present time.

\section{Results: methodology and modeling the algorithm of a decision-making process}

One of the approaches for supporting decision-making in the process is to follow a code. The most popular choices are the Code of Ethics and Guidelines for Practice by American Institute for Conservation [30], and Engineering heritage and conservation guidelines by Engineering Heritage Australia [31]. However, using codes without proper understanding may be misleading.

All relevant characteristics and circumstances regarding cultural heritage site under protection needs to be known to all parties involved in an intervention. In the ideal case, it means that there is a reliable document - nominally cultural management plan which explains the values which are under protection and provides accurate and relevant information. If such a document does not exist, it should be ordered, before any work on intervention starts. A heritage management plan is not simply a formal document which is obligatory in some countries and in all the cases of WH sites. It is a useful method which, when applied, leads to different, better and scientifically-founded solutions (for more information on a heritage management plan, see e.g. [32] or [33]).

For every decision, in theory, there are only three areas of moral thought - options, duties of special relation and constraints according to [34] after [35]. In the case of large span structures it means the following:

- Options: Examining all choices of structures which fit the requirements, looking after optimal solution for heritage. Table 2 sums up case studies from previous chapters.

Table 2. Summary of the case studies from chapter 4 .

\begin{tabular}{|c|c|c|}
\hline Type of structure & Common spans/area & Notes \\
\hline Girders & $<9 m$ & Simple and reliable \\
\hline Strut trussed girders & $9-20 m$ & $\begin{array}{l}\text { Slim looking trusses/main ad- } \\
\text { vantage is transparency }\end{array}$ \\
\hline Frames & $12-50 \mathrm{~m}$ & $\begin{array}{l}\text { Suitable when walls are pre- } \\
\text { served but weak }\end{array}$ \\
\hline Trusses & $15-50 \mathrm{~m}$ & Widely used \\
\hline Arches & $40-100 \mathrm{~m}$ & $\begin{array}{l}\text { Considerable for very large } \\
\text { spans }\end{array}$ \\
\hline Shells & $<1000 \mathrm{~m}^{2}$ & Elegant with great capacity \\
\hline Tent structures & $<2000 \mathrm{~m}^{2}$ & $\begin{array}{l}\text { Light/Convenient for reduced } \\
\text { number of foundations }\end{array}$ \\
\hline $\begin{array}{l}\text { Double-curved cable net struc- } \\
\text { tures }\end{array}$ & $1000-3000 \mathrm{~m}^{2}$ & $\begin{array}{l}\text { Suitable for compact sites with } \\
\text { round or oval shape. The min. } \\
\text { number of foundations: } 2 \text {. }\end{array}$ \\
\hline
\end{tabular}

- Duties of special relation: include all the obligations which come out of particular circumstances and stated preferences. Among numerous equal possibilities, in architecture it is possible to choose the particular according to personal preferences and that is fully acceptable as long as one truly understands own choices and the reasons beneath. In this case, among duties of special relation belong designers` preferences, previous experience, and all preferences regarding special characteristics of particular heritage site.

- Constraints: examine all constraints regarding the scope of intervention, respect for the monument, views, jeopardizing existing values, acceptable number and position of foundations etc. Cost-benefit analyses may provide additional constraints. 
As result, after this stage, there should be only a few versions of the solution which should be developed in details, with visualization. Visualization (with a fully free choice of software) enables evaluation based on symbolic and aesthetic analyses.

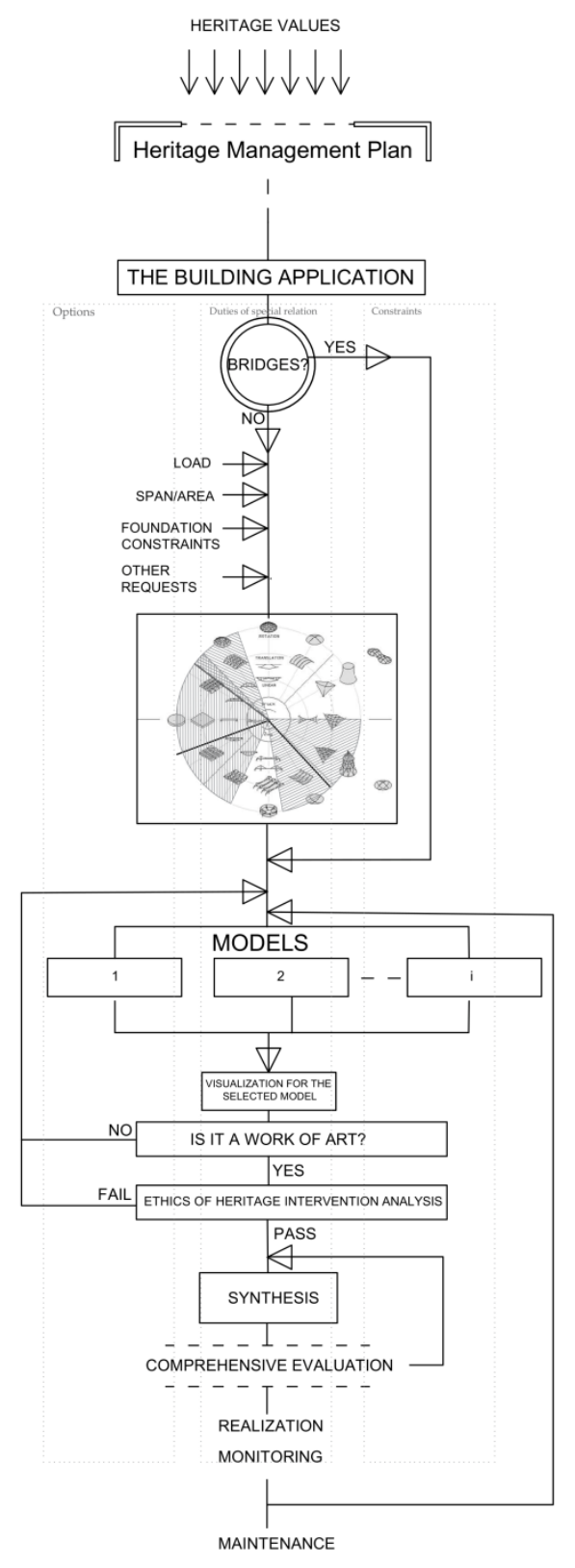

Figure 23. Algorith of decision-making process

\section{Discussion- Interventions between "needs to be done", "can be done", and "what is appropriate"}

Precondition of any success in the structural design is a good understanding of what needs to be done. That is normally described in a heritage management plan, and the very first step is fully, accurately and thoroughly understanding of values - what is protected, why, and what is the aim of the intervention?

Although the current state of construction technologies creates the general opinion that "anything can be built". One should not underestimate the difficulty of the task to resolve a highly sensitive heritage site with unique and irreplaceable values. We want to 
point out that the previous case studies reveal that a variety of additional requests may emerge. The list of technical requirements starts with high standards in safety, serviceability and durability which significantly narrow the scope of possibilities. The list may further include load/weather conditions, span, exterior and interior climate, restrictions for anchoring and size of foundations. In addition, there could be more complex demands like extensive load due to request for walkable roofs or another layering of space to provide high land efficiency through multi-functionality etc.

Heritage presentation can be an occasion for "the best of" contemporary architecture. In that context, heritage keeps a role which we are aware of for a long time, and that is the one of a catalyst of socio-economic development [36]. The consumption generated by a restoration of a heritage site is economically and socially desirable, representing the type of public works which keeps a community going forward. Heritage buildings have the privilege to be considered a priori "the right concept", similar to planting a tree. Even if choices, when, where or which type of tree, can be wrong, it is still somehow good and beneficial in general. It is similar to heritage projects. Defining appropriate within an intervention is kind of a fine adjustment which makes a good heritage project becoming a great one and it is based on the ethical values integrated into the design.

\subsection{Unexpected outcome of the research}

We want to point out the outcome of the search for examples of bridges in cases of the collision of archaeological sites and infrastructural works, for which we originally believed to be common. It is known that many archaeological sites are discovered during infrastructural works

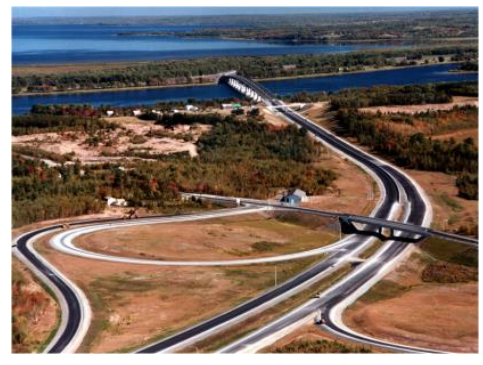

(a)

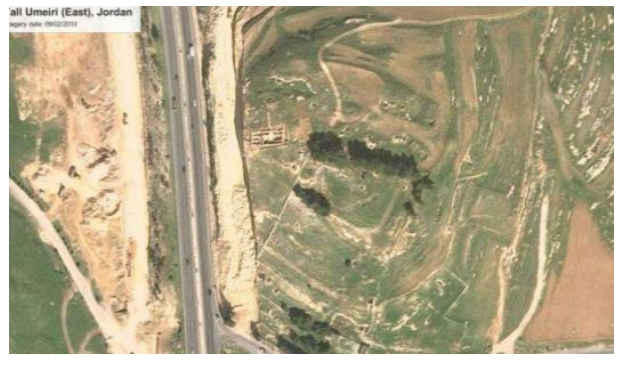

(b)

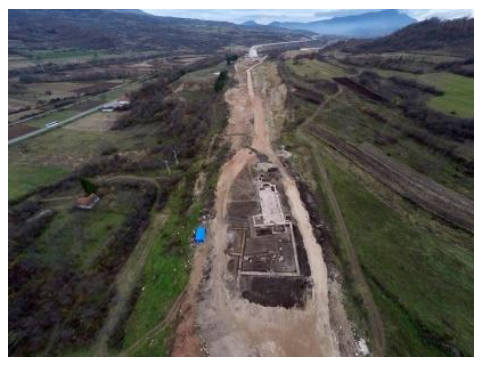

(c)

Figure 24. Different solution for collisions between archaeological sites and transport infrastructure: (a) Fredericton-Moncton highway in Canada; (b) Tall Ulmeiri (east) in Jordan; (c) Kladensce-Crnokliste (Serbia) [37-39]

However, we did not find many examples of a bridge being used for resolving such spatial conflict. Instead, we have found examples where bridges would have been natural solutions but they were not applied - instead either the infrastructure route was changed or the archaeological site was earthed. Fig 24a shows the change of road alignment for consideration of archaeological site of Maliseet First Nation (2000 years old) in New Brunswick, Canada. Fig. 24b shows a highway with the changed route, fully independent from the archaeological site which it by-passes. Fig.24c shows one of the tens of archaeological sites which were discovered along highway route between Nish (Serbia) and Bulgarian border (towards the capital, Sofia) in recent years, which overlapped with a wider area of one of the most important ancient Roman roads - VIA MILITARIS. That illustration shows huge basilica discovered in the axis of the highway (the aerial picture was taken before the site was covered again by earth). The arguments for changing a route of infrastructure in collision with heritage sites were several: fast solution, cost of construction and the maintenance of a bridge compared to cost of the new route on the ground, risk management (disaster at a bridge can cause disaster at the archaeological site), public opinion demanding a change of route etc. [34] One particular argument may be decisive - building a bridge which is only $6 \mathrm{~m}$ above the archaeological site may affect 
over $200 \mathrm{~m}$ of highway route which is disproportionally expensive compared with the benefit.

\section{Concluding remarks}

The examples used above speak in favor of the rule of thumb of construction: we (a human kind) do not build what we can but we build what we need. While resolving, out our necessities (which are functional, economical, emotional, inspirational, educational etc.,) we preserve our heritage and protect them the best we can. Often, that means that using protective buildings which, with some additional effort from our side, become works of art and future heritage of ours. Ethics of heritage interventions do not have dominant role compared to other criteria as span, load, distance between anchors/foundations and incorporating other special requests, but it may be crucial due its place in the chain of consecutive decisions, and increase number of iterations until the satisfactory result is reached.

Supplementary Materials: The following are available online:

Fig. 1. 2019,

https://www.tagesspiegel.de/berlin/der-pergamonaltar-schliesst-pergamon-museum-der-gigant-m acht-pause/10729256.html

Fig 2. Wang, B. (2014, 12 12). nextbigfuture.com. February 2021. Carnival of Space 385 Understanding dunes of Titan which are as tall as Pyramids of Egypt: https://www.nextbigfuture.com/2014/12/carnival-of-space-385-understanding.html Fig. 3. Santorini.net. (2020). Santorini Archaeological Sites. Preuzeto 2021 sa Santorini.net: https://www.santorini.net/things-to-do/santorini-archaeological-sites/

Fig. 4. By SBP

Fig.5https://www.gettyimages.com/detail/news-photo/vlotho-east-westphalia-north-rhine-westph alia-nrw-castle-news-photo/550243553\#dvlotho-east-westphalia-north-rhinewestphalia-nrw-castle -vlotho-ruin-picture-id550243553

Fig.7. Wiitenberg http://www.ig-hochbau.de/referenzen/2:reference:34/2:category:1

Fig.8.https://www.google.rs/maps/uv?hl=en\&pb=!1s0x1350dcba31d97223\%3A0x73ac40c249a429e1 !2m22!2m2!1i80!2i80!3m1!2i20!16m16!1b1!2m2!1m1!1e1!2m2!1m1!1e3!2m2!1m1!1e5!2m2!1m1!1e4!2 m2!1m1!1e6!3m1!7e115!4shttps\%3A\%2F\%2Fen.wikipedia.org\%2Fwiki\%2FPlao\%25C5\%25A1nik!5 sarchaeologi-

cal\%20site\%20ohrid\%20-\%20Google\%20Search\&imagekey=!1e10!2sAF1QipPELv2jvvoUC0gfJAuB a1RlbKQ3VnIhPxnj3NTJ\&sa=X\&ved=2ahUKEwifqIfE1ordAhUL1SwKHUb-DrAQoiowF3oECAsQ CQ

Fig.9. http://www.rittergut-lucklum.de/startseite/

Fig.11. https://homepage.univie.ac.at/elisabeth.trinkl/forum/forum0900/16dach.htm

Fig.12. https://de.wikipedia.org/wiki/Domruine_von_Hamar

Fig.13. https://en.wikipedia.org/wiki/Lepenski_Vir\#/media/File:Lepenski_Vir_(2).JPG

Fig.14. The Amazing Prehistoric Hagar Qim Temples of Malta. (2020). 2021， templeseeker.com: https://www.templeseeker.com/hagar-qim-temples-malta/

Fig.15. http://awards.intergalva.com/germany-shell.html

Fig.17. http://www.kugel-architekten.de/content.php?n=1\&d=1

Fig 18. https://www.eisat.de/allgemein/membran-schutzdach-fur-gobekli-tepe-turkei/ 
Fig.20. Brug Kidrop https://oar.onroerenderfgoed.be/publicaties/ROEV/2527/ROEV2527-001.pdf

Fig.21. Ekopolis: jun 2012 (blogger) https://images.app.goo.gl/V2m5P1pviBBmxhaw9

Fig.22. Meyer, F.: Membrandach für das Schloss, Bauwelt 22/2009, p. 22-26

Fig.24a. [Online] 2002.

https://www.canadianconsultingengineer.com/features/award-of-merit-fredericton-moncton-high way/

Fig.24b. https://www.mcc.gov/blog/entry/blog-062813-ancient-archaeological-site.

https://www.mcc.gov. [Online] 2013.

https://www.mcc.gov/blog/entry/blog-062813-ancient-archaeological-site.

Fig.24c. Google Earth

Author Contributions: Conceptualization, N.Z.L. and H.P.; methodology, N.Z.L. and H.P.; software, ; validation, N.Z.L. and H.P.; formal analysis, N.Z.L. and H.P.; investigation, N.Z.L. and H.P.; resources, N.Z.L. and H.P.; data curation, N.Z.L. and H.P.; writing-original draft preparation, N.Z.L. and H.P.; writing-review and editing, N.Z.L., H.P.; visualization, H.P. and N.Z.L. ; supervision, H.P.; project administration, N.Z.L.and H.P.; funding acquisition, H.P. Both authors have read and agreed to the published version of the manuscript.

Funding: This research received no external funding

Acknowledgments: The authors would like to thank prof. Philippe van Bogaert, who drew their attention to examples on bridges at archeological sites in Belgium.

Conflicts of Interest: The authors declare no conflict of interest.

\section{References and sources}

1. Accessed 2019 from https://www.tagesspiegel.de/berlin/der-pergamonaltar-schliesst-pergamon-museum-der-gigant-macht-pause/10729256.ht $\mathrm{ml}$

2. Wang, B. (2014, 12 12). nextbigfuture.com. February 2021. Carnival of Space 385 Understanding dunes of Titan which are as tall as Pyramids of Egypt: https://www.nextbigfuture.com/2014/12/carnival-of-space-385-understanding.html

3. Santorini.net. (2020). Santorini Archaeological Sites. Preuzeto 2021 sa Santorini.net: https://www.santorini.net/things-to-do/santorini-archaeological-sites/

4. By Prof. Schlaich, Schlaich, Bergermann und Partner, lecture on 23.05.2014 in Cottbus

5. https://www.gettyimages.com/detail/news-photo/vlotho-east-westphalia-north-rhine-westphalia-nrw-castle-news-photo/5 50243553\#dvlotho-east-westphalia-north-rhinewestphalia-nrw-castle-vlotho-ruin-picture-id550243553

6. By authors

7. By authors

8. By authors

9. http://www.rittergut-lucklum.de/startseite/

10. By authors

11. By authors

12. https://de.wikipedia.org/wiki/Domruine von Hamar

13. https://en.wikipedia.org/wiki/Lepenski Vir\#/media/File:Lepenski Vir (2).JPG

14. The Amazing Prehistoric Hagar Qim Temples of Malta. (2020). 2021, templeseeker.com: https://www.templeseeker.com/hagar-qim-temples-malta/

15. http://awards.intergalva.com/germany-shell.html

16. By authors

17. http://www.kugel-architekten.de/content.php?n=1\&d=1

18. Pasternak H., Krausche T.: Details and assembly of two cladded double curved cable net roofs. In: Advances in Engineering Materials, Structures and Systems: Innovations, Mechanics and Applications (ISBN 978-1-138-38696-9), Hrsg. Alphose Zingoni, 2019, p. 896-901

19. https://www.eisat.de/allgemein/membran-schutzdach-fur-gobekli-tepe-turkei/ 
20. by Prof. Philippe van Bogaert

21. Brug Kidrop https://oar.onroerenderfgoed.be/publicaties/ROEV/2527/ROEV2527-001.pdf

22. Minsaer Karen et Martens Femke, Eindrapport van de deinst Archeologie stad Antwerpen. 2013 https://oar.onroerenderfgoed.be/publicaties/ROEV/2527/ROEV2527-001.pdf, Feb. 2021

23. Arenghi, A. (2005). Accessibilità degli edifici storici e vincolati. 2011 from Progettare per tutti, Transformare i vincoli in oppotunitaà: http://www.progettarepertutti.org/formazione/Accessibilita_edifici_storici_ottobre2005.pdf

24. Zivaljevic-Luxor N., Kurtović-Folic N., Heritage lost in legal procedures, April 2018 DOI: 10.14415/konferencijaGFS2018.045 Conference: 6th International Conference Contemporary achievements in civil engineering At: Subotica, Republic of Serbia

25. Zivaljevic-Luxor, N., Kurtović Folić, N.: From Technical To Ethical Aspects Of Re-Using Heritage Buildings As Museums, Prvo plenarno predavanje, VSU'2017, Sofia, Proceedings of XVII International Scientific Conference VSU'2017, (V. Stoyanov, D. Partov, Eds.), 8-9 June 2017, Sofia, University “L. Karavelov”

26. Rowney, B. (2004). Charters and Ethics of Conservation, A cross-Cultural Perspective.

27. Dubois, G. (2000). A la recherce d'une ethique du tourisme. Cahiers Espaces, No 67 "Tourisme durable", 10-29.

28. Brandi C, Theory of restoration, 2005 (1971) Istituto Centrale per il Resta, ISBN-10 : 8840440895, ISBN-13 : 978-8840440897

29. Meyer, F.: Membrandach für das Schloss, Bauwelt 22/2009, p. 22-26

30. AIC. (n.d.). Our Code of $\quad$ Ethics. $\quad$ Preuzeto 2021 sa https://www.culturalheritage.org/about-conservation/code-of-ethics\#: :text=This $\% 20$ document $\% 2 \mathrm{C} \% 20$ the $\% 20 \mathrm{Code} \% 20$ of the $\% 20$ care $\% 20$ of $\% 20$ cultural\%20property.

31. Engineers Australia. (2014). Engineering Heritage Australia. Preuzeto 2021 sa Engineering Heritage and Conservation Guidelines:

https://www.engineersaustralia.org.au/sites/default/files/resource-files/2017-07/Heritage\%20\&\%20Conservation\%20Guide lines.2014\%20A.pdf

32. UNESCO. (2019). 2019 Operational Guidelines for the Implementation of the World Heritage Convention. Paris: UNESCO.

33. UNESCO, ICCROM, ICOMOS, IUCN. (2013). Managing Cultural World Heritage. Paris.

34. Pasternak , H., Zivaljevic-Luxor, N. (2018). Bridges for integration of archaeological sites into metropolitan area. 18th International scientificc conference for construction and architecture VSU 2018. Sofia: VSU.

35. Sandis Constantine (ed) Cultural Heritage Ethics Between theory and practice, Open book Publishers, 2014, ISBN Digital (pdf):978-1-78374-070-3

36. Zivaljevic-Luxor, N., \& Kurtovic-Folic, N. (2014). The third generation of planning the Cultural Heritage Future. Proceedings of 14th international Scientific conference for construction and architecture VSU 2014 5-6.60214. Sofia: VSU.

37. Fig.24a. [Online] 2002.

https://www.canadianconsultingengineer.com/features/award-of-merit-fredericton-moncton-highway/

38. Fig.24b. https://www.mcc.gov/blog/entry/blog-062813-ancient-archaeological-site. https://www.mcc.gov. [Online] 2013. https://www.mcc.gov/blog/entry/blog-062813-ancient-archaeological-site.

39. Fig.24c. Google Earth 